\title{
PARTISIPASI PEREMPUAN DALAM BIDANG POLITIK DI SUMATERA BARAT
}

\author{
Oleh
}

\section{Dr.Firman.MS (PSW UNP), Prof.Dra.Sjahridal Dahlan.M.Sc (PSW \\ Unand),Dra.Jusnaini.M.Si (PSW UNP), Dra.Hj,Hilda Marni Intan (PSW STAIN BT),Hasranita.SH.MH (PUSPER UBH),Dra.Luli Sariyustina.M.Pd.(PUSPER UNES),Dra.Elwis Nazar.M.Ag (PSW IAIN IB),Suswati Hendriani. S.Pd. M.Pd. (PSG STAIN BSK),Lilisuswita.SE.MM (PSW UMSB)}

\section{Email : firman@konselor.org}

\section{A. Pendahuluan}

Pembagunan merupakan proses perubahan, dimana kemiskinan dihapuskan dan kreatifitas serta tingkat pengetahuan masyarakat dari berbagai lapisan ditingkatkan menuju kemandirian dan kemakmuran. Pengalaman yang ditempuh selama ini kebanyakan program pembangunan tidak mengikutsertakan perempuan secara maksimal. Pada tingkat perencanaan dan pelaksanaan, perempuan tidak memiliki akses yang sama dengan laki-laki untuk berpartisipasi. Sementara itu, informasi tentang peluang dalam program pembangunan tidak jarang hanya dimotori dan dilakukan oleh kaum laki-laki.

Paradigma pembangunan manusia yang meletakkan masyarakat sebagai pusat perhatian seharusnya berwawasan gender. Meutia Hatta Swasono (www.swara.tv/id/view berita.php?ID B=9) mengungkapkan setiap upaya pembangunan berwawasan gender seharusnya mencakup sedikitnya tiga prinsip, yaitu: (1) kesetaraan hak antara perempuan dan laki-laki diabadikan sebagai prinsip fundamental, (2) perempuan diakui sebagai agen dan pewaris perubahan, (3) model pembangunan baru yang berperspektif gender meskipun bertujuan untuk memperluas pilihan-pilihan perempuan dan laki-laki tidak menganggap perbedaan budaya dan masyarakat sebagai sesuatu yang bersifat kodrati.

Berbagai usaha sudah dilakukan pemerintah untuk meningkatkan status dan kedudukan perempuan dalam semua aspek pembangunan, selain dicantumkan dalam Garis-garis Besar Haluan Negara (GBHN) 1999 dan Undang-Undang (UU) Nomor 25 Tahun 2000 tentang Program Pembangunan Nasional, juga diterbitkan Instruksi Presiden (Inpres) Nomor 9 Tahun 2000 tentang Pengarusutamaan Jender dalam pembangunan nasional (www.kompas.com/kompas- 
cetak/0106/13/iptek/khof10.htm). Di sisi lain, seiring dengan bergulirnya era reformasi, bermunculan berbagai organisasi yang memfokuskan dirinya bagi upaya-upaya meningkatkan partisipasi perempuan dalam politik. Organisasi tersebut, diantaranya : Kaukus Perempuan di Parlemen, Kaukus Perempuan Politik Indonesia, Pusat Pemberdayaan Perempuan dalam Politik (PP-POL), Gerakan Pemberdayaan Suara Perempuan (GPSP), Jaringan Perempuan dan Politik dan lain sebagainya. Peningkatan partisipasi perempuan perlu diperjuangkan secara serius. Momentum ke arah itu muncul ketika pemerintah mengeluarkan kebijakan politik untuk merevisi Undang-Undang Pemilu yang sangat strategis untuk memulai perubahan (UU Pemilu No.12 Tahun 2003) walaupun belum menunjukan hasil yang memuaskan.

Secara realistis, perjuangan meningkatkan partisipasi perempuan pada tahap selanjutnya menemui banyak kendala. Walaupun secara kuantitas jumlah perempuan melebihi laki-laki, namun perempuan semakin menunjukkan ketidak berdayaan, karena perannya di berbagai lembaga politik formal atau pengambilan keputusan politik, baik di lembaga legislatif, eksekutif maupun yudikatif masih belum terwakili secara seimbang.

Kondisi tersebut disebabkan, pertama adanya budaya patriakhi yang memang harus diakui secara kuat, telah mencemari seluruh dimensi kehidupan bangsa Indonesia, termasuk di dalamnya sistim politik yang kita miliki. Sebagian besar masyarakat bahkan perempuan itu sendiri masih banyak memandang pembagian kerja secara seksual, ada perbedaan yang jelas dan tegas tentang wilayah kerja yang menjadi milik perempuan dan laki-laki. Kedua, berkaitan dengan kualitas kaum perempuan sendiri yang banyak tertinggal dibandingkan dengan laki-laki. Walaupun ini adalah persoalan klasik namun tidak dapat dianggap sederhana. Ketiga, terkait dengan peran ganda yang harus dimainkan oleh perempuan, yakni sebagai perempuan yang tidak dapat melepaskan diri dari fungsi-fungsi reproduksi yang tidak bisa diwakilkan.

Partisipasi perempuan dalam politik tidak selalu harus duduk dalam pemerintahan atau parlemen, sebab pada posisi tersebut yang paling dipentingkan adalah orang yang memiliki kesadaran tentang kesetaraan gender. Partisipasi perempuan dapat saja dilakukan dalam posisinya sebagai rakyat biasa dengan 
kesadaran politik penuh. Sebagai langkah awal dari fungsi perempuan sebagai warga negara adalah keterlibatan mereka dalam pemilihan umum sebagai kontak mereka dengan negara.

Walaupun demikian partisipasi perempuan dalam pembangunan masih terbatas. Berdasarkan hasil penelitian Smeru (www. Smeru .or . id / newslet /1999 led0 /field61. htm) ditemukan hanya sekitar 10\% sampai $20 \%$ dari pengurus Forum Kelurahan dan anggota gugus tugas di Cibangkong, Bandung adalah perempuan. Hal itu bertentangan dengan jumlah perempuan dalam masyarakat tersebut yang hampir $60 \%$ dari total polulasi lokal. Keadaan serupa juga ditemui di Kelurahan Forum di Kamal Muara, Jakarta Utara. Uji coba Pemantauan Swadaya Masyarakat di Kecamatan Gangga dan Sekotong, Lombok Barat bahkan lebih memprihatinkan lagi. Di dua Forum Kecamatan itu, hampir seluruh staf dan anggota gugus tugasnya laki-laki. Selanjutnya Khofifah (www.kompas.com/kompas-cetak/0106/13/iptek/khof10.htm) mengungkapkan pada Pemilihan Umum (Pemilu) 1999, 57 persen pemilih adalah perempuan. Akan tetapi, anggota legislatif perempuan di DPR hanya 8,8\%, lebih rendah dari Pemilu tahun 1997 yang berjumlah 11,2 \%. Jumlah perempuan pegawai negeri sipil (PNS) yang menduduki jabatan struktural hanya 15,2\%, sedang PNS laki-laki 84,8 \% (www.kompas.com/kompas-cetak/0106/13/iptek/khof10.htm).

Selanjutnya Kresno Agus Hendarto (www. dephut. go. id/INFORMASI/SocFor/Gender. htm) menjelaskan ketimpangan posisi perempuan Indonesia dibandingkan dengan laki-laki dalam bidang politik, terlihat pada tabel berikut ini.

\section{Tabel 1 : Posisi Perempuan Dibandingkan dengan Laki-laki di Indonesia}

$\begin{array}{ll}\text { No.Posisi Perempuan dalam Pemerintah/ Politik } & \text { Keterlibatan } \\ \text { 1. * DPR } & 43(\mathbf{8 , 3 \%}) \\ \text { 2. * MPR } & 63(\mathbf{9 , 1 \%}) \\ \text { 3. * DPA } & 1(\mathbf{2 , 5 \% )} \\ \text { 4. * BPK } & 0 \\ \text { 5. * MA } & 7(14,8 \%) \\ \text { 6. * KPU } & 2(18,1 \%) \\ \text { 7. * Gub/ Wakil Gub } & 0 \\ \text { 8. * Bupati/ Walikota } & 7(6,0 \%) \\ \text { 9. * Dubes } & 4(0,5 \%) \\ \text { 10.* Ketua Partai Politik } & 1\end{array}$


Partisipasi perempuan dibidang politik di Sumatera Barat masih terbatas walaupun affirmatif Action melalui UU No.12 Tahun 2003 tentang penetapan kuota $30 \%$ telah dicanangkan. Fatmariza (2004) menjelaskan keterwakilan perempuan di lembaga legislatif di DPRD Propinsi Sumatera Barat hasil Pemilu 2004, yaitu 9,09 \%, sedangkan keterwakilah perempuan di Kabupaten/Kota sangat bervariasi dan bahkan masih ada daerah yang belum memiliki anggota legislatif perempuan. Selanjutnya Indrati (2004) menjelaskan semakin tinggi tingkat eselon semakin sedikit jumlah perempuan yang menduduki posisi tersebut dan sebaliknya esselok II didominasi laki-laki 100 \%, esselon III, 91 \% laki-laki dan 9 \% perempuan, esselon IV 68,35 \% laki-laki dan 31,65\% perempuan. Untuk jabatan kepala sekolah pada jenjang pendidikan SD/MI berimbang antara laki-laki dan perempuan 53,48 \% dan 46,42\%, sedangkan SMP/MTS 86,19\% dan 13,81 $\%$, SMA/MA 87,05 \% dan 12,95 \%, SMK 89,58 \% dan 10,41\%.

Sehubungan dengan hal itu, terlihat partisipasi perempuan dalam bidang politik selama ini masih menjadi barang langka, salah satu indikasi disebabkan oleh kuatnya kultur patriakhi, keterbatasan perempuan, kurangnya pemahaman, lemahnya daya saing perempuan dan budaya diam. Kuatnya budaya patriakhi berakar pada perspektif tentang kondrat, tugas dan peran perempuan secara tradisional meniscayakan bahwa peranan fungsi perempuan diidentifikasikan sebagai pelaku peran reproduksi dan peran domestik lainnya. Ketertinggalan perempuan juga disebabkan oleh keterbatasan dan ketidakmampuan perempuan untuk berkompetisi dengan laki-laki.

Berkaitan dengan hal itu, Fatmariza (2004) mengungkapkan partisipasi perempuan anggota dan calon anggota legislatif di bidang politik di Sumatera Barat ditemukan, anggota terpilih 47,7 \% mempunyai pengalaman organisasi dan partai politik baik, sedangkan 19,9 \% mempunyai kategori yang kurang. Bagi calon yang tidak terpilih 40,1 \% mempunyai pengalaman yang kurang dalam organissi kemasyarakatan dan 49,2 \% kurang dalam politik. Pada umumnya pemilihan caleg hanya sekedar memenuhi syarat yang ditetapkan KPUD, sehingga caleg hanya asal ada saja.

Perempuan masih diletakkan sebagai obyek, langkah-langkah yang diambil dan dikembangkan kurang mempertimbangkan perempuan dengan segala potensi 
yang dimilikinya. Paradigma ini telah gagal mengembangkan akar pembangunan politik yang berbasis pada masyarakat termasuk perempuan lokal. Mencermati permasalahan tersebut, di Era Reformasi dilakukan langkah-langkah dan pendekatan pembangunan dari top down menjadi buttom up. Pelaksanaan pembagunan selanjutnya dilakukan melalui proses desentralisasi dan pemberlakuan UU Nomor 22/1999 tentang otonomi daerah.

Seiring dengan pelaksanaan otonomi daerah di Indonesia, pembangunan daerah di Sumatera Barat dilaksanakan melalui Perda No. 9 Tahun 2000 tentang Ketentuan Pokok Pemerintahan Nagari. Peraturan Daerah ini menjelaskan bahwa unit pemerintahan terendah di Sumatera Barat adalah pemerintahan nagari yang sesuai dengan konsep adat istiadat Minangkabau. Pemerintahan nagari berhak menyelenggarakan pembangunan berdasarkan otonomi asli yang dimilikinya. Di samping itu, pemerintah nagari dapat mengembangkan peran serta seluruh lapisan masyarakat secara demokratis dengan memfungsikan peran lembaga adat dan lembaga lainnya sebagai mitra kerja dalam rangka pemberdayaan masyarakat (Penjelasan Perda Sumatera Barat No. 9 Tahun 2000).

Kondisi pemerintahan dalam pelaksanaan otonomi daerah di Sumatera Barat memungkinkan perempuan berpartisipasi dalam bidang politik, karena jumlah penduduk perempuan lebih banyak dibandingkan dengan laki-laki di Sumatera Barat. Koentjaraningrat ( 1985 : 79 ) menjelaskan partisipasi adalah memberikan sumbangan dalam pembangunan dan turut menentukan arah atau tujuan pembangunan.

Partisipasi perempuan dalam bidang politik menjadi sangat penting, karena merekalah yang memahami potensi yang dimilikinya dan bisa dikembangkan untuk keberlangsungan kehidupan dan masa depan mereka. Kenyataan yang ditemui menurut Eko Bambang S (2004: www. jurnalperempuan. com/yjp.jpo/?act=berita\%7C-277\%7CN) mengungkapkan otonomi daerah masih mengesampingkan peran perempuan. Salah satu indikasinya dapat dilihat proses pengambilan keputusan di tingkatan daerah, perempuan seringkali tidak dilibatkan. Kebijakan otonomi daerah justru menjauhkan peran perempuan dalam konteks pembangunan daerah. Perempuan justru dijadikan sebagai objek sasaran yang tidak menguntungkan bagi kemajuan dirinya. 
Berdasarkan grand tour di salah satu nagari di Sumatera Batat ditemukan, pengambilan keputusan dalam pembangunan nagari jarang dilibatkan melibatkan perempuan. Kalau mereka diundang untuk rapat dalam pengambilan keputusan tersebut, hanya berperan di seksi konsumsi dan sekretaris. Begitu juga posisiposisi yang diserahi kepadanya dalam organisasi sosial di Nagari/kelurahan. Perempuan di Nagari berpandangan, seksi yang ditugaskan kepadanya tidak membutuhkan pemikiran dan penentu dalam pengambilan kebijakan. Apabila mereka mengajukan saran/ide dalam rapat atau pertemuan lainnya tidak jarang dilecehkan, karena dianggap kemampuan perempuan dalam bidang politik terbatas. Jika mereka diberi kesempatan menjalankan posisi penting, dukungan yang diterima terbatas dan akhirnya perkerjaan kurang mengenai sasaran yang diinginkan. Kegagalan perempuan menjalankan tugas yang diberikan kepadanya, bersumber dari keterbatasan kemampuan mereka di Bidang politik.

Bertitik tolak dari uraian tersebut menarik ditelusuri lebih lanjut melalui penelitian ini adalah bagaimana pemahaman perempuan terhadap politik, duukungan Sosial terhadap perempuan dalam bidang politik serta partisipasi perempuan dalam bidang politik di lingkungan masyarakat Sumatera Barat. Pengungkapan masalah ini sangat bermanfaat sebagai bahan pertimbangkan dalam pengambilan kebijakan pemberdayaan perempuan di bidang politik di Sumatera Barat.

\section{B. Metode Penelitian}

Penelitian ini menggunakan pendekatan kuantitatif. Pendalaman data tentang partisipasi perempuan dalam bidang politik di lanjutkan dengan wawancara, observasi, analisis dokumen dan Focus Group Discus. Populasi penelitian ini adalah perempuan dalam masyarakat di Kabupaten/Kota Propinsi Sumatera Barat, dengan karakteristik berpendidikan minimal tamatan Sekolah Lanjutan Pertama, Mewakili Bundokanduang, tokoh masyarakat serta tokoh agama lainnya.

Menghindari kesulitan dalam menyusun sampling frame secara individu serta menjaring perempuan di Kabupaten/Kota, pengambilan sampel menggunakan teknik Two Stage Cluster Random Sampling. Perempuan di 
Kabupaten/Kota diklasifikasikan ke dalam dua strata, yaitu : stratum perempuan dari Kabupaten dan Kota Propinsi Sumatera Barat. Unit Sampling Primer (USP) adalah perempuan di Kabupaten/Kota dan Unit Sampling Sekunder (USS) serta juga menjadi unit observasi adalah perempuan di Kabupaten/Kota Propinsi Sumatera Barat.

Untuk pemilihan tahap pertama secara acak dipilih perempuan dari masingmasing stratum. Kabupaten terpilih yaitu Kabupaten Tanah Datar, Kabupaten Pasaman, Kabupaten Agam dan Kabupaten Solok. Sedangkan kota yang terpilih adalah Kota Padang, Kota Sawahlunto, Kota Bukittinggi dan Kota Payakumbuh.. Pilihan tingkat ke dua dipilih perempuan dari Kabupaten/Kota terpili. Data yang diperlukan dalam penelitian ini dikumpulkan dengan angket, wawancara, observasi, analisis dokumen dan Focus Group Discus.

Data yang diperoleh dianalisis secara deskriptif, dengan menggunakan persentase. Selanjutnya data tersebut dianalisis secara kualitatif, dengan melakukan langkah utama membuat klasifikasi merumuskan kategori-kategori sampai kepada penafsiran arti dari jawaban yang ada. Model yang digunakan dalam menganalisis data adalah pola yang dikembangkan oleh Miles dan Huberman, dengan kegiatan (1) reduksi data, (2) penyajian data, (3) penarikan kesimpulan dan verivikasi, (4) merumuskan temuan, (5) membuat laporan hasil penelitian.

\section{Hasil Penelitian dan Pembahasan}

\section{Hasil Penelitian}

Berdasarkan hasil penelitian terhadap perempuan di Kabupaten/Kota Propinsi Sumatera Barat sebagai lokasi penelitian, ditemukan sebagai berikut :

\section{a. Pemahaman Politik Perempuan di Sumatera Barat}

Berdasarkan hasil penelitian dan pengolahan data diperoleh informasi tentang pemahaman politik perempuan di Sumatera Barat seperti tabel berikut ini : 
Tabel 1

Distribusi Frekuensi Pemahaman Politik Perempuan di Propinsi Sumatera Barat

\begin{tabular}{|l|l|c|c|c|c|c|c|c|}
\hline \multirow{2}{*}{ No. } & \multirow{2}{*}{ Indikator } & \multicolumn{5}{|c|}{ Kemungkinan Jawaban } & \multirow{2}{*}{ Jml } \\
\cline { 3 - 8 } & & \multicolumn{2}{|c|}{ Ya } & \multicolumn{2}{c|}{ Ragu-ragu } & \multicolumn{2}{c|}{ Tidak } & \\
\cline { 3 - 8 } & & $\mathrm{f}$ & $\%$ & $\mathrm{f}$ & $\%$ & $\mathrm{f}$ & $\%$ & \\
\hline 1. & Menterjemahkan & 229 & 47.71 & 85 & 17.71 & 166 & 34.58 & 480 \\
\hline 2. & Menafsirkan & 792 & 55 & 195 & 13.54 & 453 & 31.46 & 1440 \\
\hline 3. & Ekstra Polari & 584 & 45.63 & 138 & 10.78 & 558 & 43.59 & 1280 \\
\hline & Jumlah & 1605 & 50.16 & 418 & 13.06 & 1177 & 36.78 & 3200 \\
\hline
\end{tabular}

Berdasarkan tabel di atas, ditemukan sebanyak $47.71 \%$ perempuan di Propinsi Sumatera dapat menterjemahkan perlunya keterlibatan perempuan mempengaruhi kebijakan pemerintah dalam pengambilan keputusan. Selanjutnya sebanyak $34.58 \%$ tidak dapat dan $17.71 \%$ ragu-ragu menterjemahkan perlunya keterlibatan perempuan mempengaruhi kebijakan pemerintah dalam pengambilan keputusan. Secara umum ditemukan sebagian besar perempuan di Propinsi Sumatera Barat belum dapat menterjemahkan perlunya keterlibatan perempuan mempengaruhi kebijakan pemerintah dalam pengambilan keputusan secara maksimal $(52.29 \%=34.58 \%$ telah dapat + $17.71 \%$ ragu-ragu).

Dalam hal menafsirkan keterlibatan perempuan mempengaruhi kebijakan pemerintah mengambil keputusan, ditemukan sebanyak $55 \%$ dapat menafsirkan pentingnya keterlibatan perempuan. Selanjutnya sebanyak 31.46 \% tidak dapat dan $13.54 \%$ ragu-ragu menafsirkan pentingnya keterlibatan perempuan mempengaruhi kebijakan pemerintah dalam pengambilan keputusan. Sehubungan dengan hal itu, secara umum ditemukan perempuan Propinsi Sumatera Barat belum dapat menafsirkan pentingnya keterlibatan perempuan mempengaruhi kebijakan pemerintah dalam pengambilan 
keputusan secara maksimal $(45 \%=31.46 \%$ tidak dapat $+13.54 \%$ raguragu) .

Selanjutnya dalam hal ekstrapolari, ditemukan sebanyak $45.63 \%$ dapat mempertimbangkan/meramalkan (extrapolari) pentingnya keterlibatan perempuan mempengaruhi kebijakan pemerintah mengambil keputusan. Selanjutnya $43.59 \%$ menyatakan tidak dapat dan $10.78 \%$ ragu-ragu menafsirkan keterlibatan perempuan mempengaruhi kebijakan pemerintah dalam pengambilan keputusan. Secara umum ditemukan sebagian besar perempuan Propinsi Sumatera Barat belum dapat mempertimbangkan/meramalkan (extrapolari) pentingnya keterlibatan perempuan mempengaruhi kebijakan pemerintah mengambil keputusan secara maksimal ( $54.37 \%=43.59 \%$ tidak dapat $+10.78 \%$ ragu-ragu $)$.

Apabila dikalkulasikan lebih lanjut ketiga indicator tersebut di atas, secara umum ditemukan sebanyak 50.16 \% perempuan Propinsi Sumatera Barat dapat menterjemahkan, menafsirkan dan extrapolari (mempertimbangkan/meramalkan) perlunya keterlibatan perempuan mempengaruhi kebijakan pemerintah dalam pengambilan keputusan. Selanjutnya sebanyak $36.78 \%$ tidak dapat dan $13.06 \%$ ragu-ragu menterjemahkan, menafsirkan dan extrapolari (mempertimbangkan/meramalkan) perlunya keterlibatan perempuan mempengaruhi kebijakan pemerintah dalam pengambilan keputusan. Dengan demikian sebagian besar perempuan Propinsi Sumatera Barat belum dapat menterjemahkan, menafsirkan dan extrapolari (mempertimbangkan/meramalkan) perlunya keterlibatan perempuan mempengaruhi kebijakan pemerintah dalam pengambilan keputusan secara maksimal $(49.84 \%=36.78 \%$ tidak dapat $+13.06 \%$ ragu-ragu $)$.

Keterbatasan pemahaman politik perempuan di Sumatera Barat, menurut informan salah satu indikasi penyebab kurang berpihaknya perempuan terhadap perempuan dalam politik. Hal inilah salah satu penyebab gagalnya quata keterwakilan perempuan dalam pemilihan umum direalisasikan. Menurut sebagian besar tokoh masyarakat di lokasi penelitian mengungkapkan perempuan tersebut harus ditingkatkan pengetahuannya menyangkut dengan organisasi dan kemasyarakatan. Perempuan yang akan 
terjun ke dunia politik dituntut memiliki : keberanian/keamanan, keterampilan, pengetahuan dan waktu yang cukup.

Peningkatan pengetahuan perempuan dalam bidang politik dapat dilakukan melalui pendidikan politik, sehingga pada gilirannya perempuan tersebut dapat menjadi tokoh dalam masyarakat. Ketokohan perempuan tidak muncul hanya diwaktu akan Pemilu saja, tetapi jauh hari sebelumnya seharusnya sudah memperlihatkan kiprahnya di lingkungan masyarakat. Masyarakat akan memilih perempuan yang berkualitas, tetapi kenyataannya perempuan berkualitas takut berpolitik karena mereka menganggap dunia politik adalah dunia kotor dan penuh kejahatan. Di samping aturan pemerintah terhadap quato $30 \%$ setengah-setengah dan tidak ada sangsinya apabila tidak dilaksanakan. Papol seharusnya bukan menampilkan perempuan asal memenuhi syarat aturan yang telah digariskan.Perempuan yang masuk Parpol seharusnya berilmu, punya waktu, dana dan kemampuan. Sebaiknya perempuan jangan mau diobjekan laki-laki untuk memenuhi quota $30 \%$.

Berdasarkan kenyataan di DPRD, berdasarkan informasi dari sebagian besar perempuan anggota dewan mengungkapkan sebenarnya tidak ada halangan perempuan dalam politik. Kondisi yang ditemui adalah kurangnya penghargaan dan diskriminasi terhadap perempuan. Begitu juga kebiasaan sesama perempuan yang saling menjatuhkan dan perempuan lain tidak mengakui keunggulan teman sejenisnya. Kondisi ini diperburuk apabila kondisi keluarga perempuan yang aktif dalam kegiatan politik tidak berjalan sebagaimana mestinya. Begitu juga informasi dari Bundokanduang yang mengungkapkan perilaku anak perempuan dewasa ini jauh lebih berani dan berperan dalam kegiatan organisasi kemasyarakatan, misalnya kegiatan PKK, Posyandu di Kelurahan/Nagari. Apabila perempuan diberi kesempatan mereka akan dapat meningkatkan peranannya di masyarakat.

Kemauan anak perempuan tersebut hilang diperjalanan waktu apabila mereka telah berumah tangga atau bekerja pada salah satu instansi. Sebagian besar suami dan anak-anak mengiginkan ibu melakukan pekerjaan domestik saja, karena menganggap dunia politik itu keras dan bukan diperuntukan untuk perempuan. Kondisi ini salah satu indikasi menyebabkan kurang berkembangnya perempuan di masyarakat. Banyak perempuan diwaktu menjalani pendidikan di sekolah memiliki pretasi berlian setelah berumah 
tangga semuanya hilang. Peningkatan pengetahuan perempuan diperlukan guna pemberdayaan perempuan dalam bidang politik di Kelurahan/Nagari.

\section{b. Dukungan Sosial yang Diterima Perempuan dalam Kegiatan Politik}

Berdasarkan hasil penelitian dan pengolahan data diperoleh informasi tentang dukungan sosial yang diterima perempuan di Sumatera Barat dalam kegiatan politik seperti tabel berikut ini :

Tabel 2

Distribusi Dukungan Sosial Terhadap Perempuan dalam Kegiatan Politik di Sumatera Barat

\begin{tabular}{|c|c|c|c|c|c|c|c|c|c|c|c|c|}
\hline \multirow[t]{3}{*}{ No. } & \multirow[t]{3}{*}{ Indikator } & \multicolumn{10}{|c|}{ Kemungkinan Jawaban } & \multirow[t]{3}{*}{$\mathrm{Jml}$} \\
\hline & & \multicolumn{2}{|c|}{$\mathrm{SS}$} & \multicolumn{2}{|c|}{$\mathrm{S}$} & \multicolumn{2}{|c|}{$\mathrm{J}$} & \multicolumn{2}{|c|}{ JS } & \multicolumn{2}{|c|}{$\mathrm{TP}$} & \\
\hline & & $f$ & $\%$ & $\mathrm{f}$ & $\%$ & $\mathrm{f}$ & $\%$ & $\mathrm{f}$ & $\%$ & $\mathrm{f}$ & $\%$ & \\
\hline 1. & $\begin{array}{l}\text { Dukungan } \\
\text { Material }\end{array}$ & 96 & 20 & 173 & 36.04 & 108 & 22.5 & 43 & 8.96 & 60 & 12.5 & 480 \\
\hline 2. & $\begin{array}{l}\text { Dukungan } \\
\text { Emosional }\end{array}$ & 383 & 21.76 & 524 & 29.77 & 403 & $\begin{array}{c}22.9 \\
0\end{array}$ & 180 & $\begin{array}{c}10.2 \\
3\end{array}$ & 270 & 15.34 & $\begin{array}{l}176 \\
0\end{array}$ \\
\hline 3. & $\begin{array}{l}\text { Dukungan } \\
\text { Informasi }\end{array}$ & 95 & 14.84 & 262 & 40.94 & 136 & $\begin{array}{c}21.2 \\
5\end{array}$ & 52 & 8.13 & 95 & 14.84 & 640 \\
\hline 4. & Bimbingan & 134 & 27.92 & 80 & 16.67 & 108 & 22.5 & 53 & $\begin{array}{c}11.0 \\
4\end{array}$ & 105 & 21.87 & 480 \\
\hline 5. & $\begin{array}{l}\text { Bantuan } \\
\text { Fisik }\end{array}$ & 69 & 21.56 & 126 & 39.38 & 49 & $\begin{array}{c}15.3 \\
1\end{array}$ & 22 & 6.88 & 54 & 16.88 & 320 \\
\hline 6. & $\begin{array}{l}\text { Umpan } \\
\text { Balik }\end{array}$ & 41 & 12.81 & 177 & 55.32 & 54 & $\begin{array}{c}16.8 \\
7\end{array}$ & 16 & 5 & 32 & 10 & 320 \\
\hline & Jumlah & 818 & 20.45 & $\begin{array}{c}134 \\
2\end{array}$ & 33.55 & 858 & $\begin{array}{c}21.4 \\
5\end{array}$ & 366 & 9.15 & 616 & 15.4 & $\begin{array}{l}400 \\
0\end{array}$ \\
\hline
\end{tabular}

Berdasarkan tabel di atas, ditemukan $36.04 \%$ perempuan dalam kegiatan politik di Sumatera Barat mengungkapkan sering menerima dukungan social dalam bentuk dukungan material untuk beraktifitas. Selanjutnya $22.5 \%$ jarang, $20 \%$ sering sekali, $12.5 \%$ mengungkapkan tidak pernah, dan $8.96 \%$ jarang sekali menerima dukungan social dalam bentuk dukungan material untuk 
beraktifitas. Dengan demikian secara umum ditemukan perempuan dalam kegiatan politik di Sumatera Barat belum menerima dukungan social dalam bentuk dukungan material secara optimal untuk beraktifitas $(50 \%=22.5 \%$ jarang +12.5 tidak pernah $+8.96 \%$ jarang sekali).

Dukungan social dalam bentuk dukungan emosional diterima perempuan dalam kegiatan politik di Sumatera Barat, ditemukan sebanyak $29.77 \%$ mengungkapkan sering menerima dukungan emosional. Selanjutnya sebanyak 22.90. \% perempuan dalam kegiatan politik mengungkapkan jarang, $21.76 \%$ sering sekali, $15.34 \%$ tidak pernah, dan $10.23 \%$ mengungkapkan jarang sekali menerima dukungan social dalam bentuk dukungan emosional dalam beraktifitas. Secara umum ditemukan sebagian besar perempuan dalam kegiatan politik di Sumatera Bart belum menerima dukungan social dalam bentuk dukungan emosional dalam beraktifitas secara optimal $(48.47 \%=22.90 \%$ Jarang $+15.34 \%$ tidak pernah $+10.23 \%$ jarang sekali)

Di samping itu, dukungan. social dalam bentuk dukungan informasi diterima perempuan dalam kegiatan politik di Sumatera Barat, ditemukan sebanyak 40,94\% mengungkapkan sering menerima dukungan sosial dalam bentuk dukungan informasi. Selanjutnya sebanyak 21,25\% mengungkapkan jarang , $14.84 \%$ tidak pernah, $14.84 \%$ sering sekali dan $8.13 \%$ perempuan dalam kegiatan politik di Kota Bukittinggi mengungkapkan jarang sekali menerima dukungan social dalam bentuk dukungan informasi dalam beraktifitas. Secara umum ditemukan sebagian besar perempuan dalam kegiatan politik di Sumatera Barat belum menerima dukungan social dalam bentuk dukungan informasi dalam beraktifitas $(44.22 \%=21.25 \%$ jarang, $14.84 \%$ tidak pernah, dan $8.13 \%$ jarang sekali.).

Dukungan. social dalam bentuk bimbingan yang diterima perempuan dalam kegiatan politik di Sumatera Barat, ditemukan sebanyak $27.92 \%$ mengungkapkan sering sekali menerima dukungan social dalam bentuk bimbingan dalam beraktifitas. Selanjutnya sebanyak $22.5 \%$ mengungkapkan jarang, $21.87 \%$ tidak pernah, dan $16.67 \%$ sering dan $11.04 \%$ jarang sekali menerima dukungan social dalam bentuk bimbingan dalam beraktifitas. Secara umum ditemukan sebagian besar perempuan dalam kegiatan politik di Sumatera Barat belum menerima secara optimal dukungan social dalam bentuk dukungan 
bimbingan dalam beraktifitas secara optimal. $(55.41 \%=22.5 \%$ jarang + $21.87 \%$ tidak pernah $+11.04 \%$ jarang sekali).

Dukungan. social dalam bentuk bantuan fisik yang diterima perempuan dalam kegiatan politik di Sumatera Barat ditemukan sebanyak $39.38 \%$ mengungkapkan sering menerima dukungan social dalam bentuk bantuan fisik dalam beraktifitas. Selanjutnya sebanyak $21.56 \%$ mengungkapkan sering sekali, $16.88 \%$ tidak pernah dan $6.88 \%$ mengungkapkan jarang sekali menerima dukungan social dalam bentuk bantuan fisik dalam beraktifitas. Secara umum ditemukan sebagian besar perempuan dalam kegiatan politik di Sumatera Barat belum menerima dukungan social dalam bentuk bantuan fisik dalam beraktifitas secara opimtal $(39.07 \%=15.31$ jarang +16.88 Tidak pernah $+6.88 \%$ jarang seekali).

Dukungan. social dalam bentuk umpan balik yang diterima perempuan dalam kegiatan politik di Sumatera Barat, ditemukan sebanyak $55.32 \%$ mengungkapkan sering menerima dukungan social dalam bentuk umpan balik dalam beraktifitas. Selanjutnya sebanyak 16.87 \% mengungkapkan jarang, 12.81 $\%$ sering sekali, $10 \%$ mengungkapkan tidak pernah dan $5 \%$ mengungkapkan jarang sekali menerima dukungan social dalam bentuk umpan balik dalam beraktifitas. Secara umum ditemukan sebagian besar perempuan dalam kegiatan politik di Sumatera Barat belum menerima dukungan social dalam bentuk umpan balik dalam beraktifitas secara optimal $(31.87 \%=16.87 \%$ jarang +5 Jarang sekali $+10 \%$ tidak pernah)

Apabila dikalkulasikan lebih lanjut berdasarkan hasil penelitian ditemukan sebanyak $33.55 \%$ perempuan dalam kegiatan politik di Sumatera Barat mengungkapkan sering menerima dukungan social dalam bentuk dukungan material, informasi, bimbingan, bantuan fisik dan umpan balik dalam beraktifitas. Selanjutnya sebanyak $21.45 \%$ mengungkapkan jarang, $20.45 \%$ sering sekali, $15.4 \%$ tidak pernah dan $9.15 \%$ mengungkapkan jarang sekali menerima dukungan social dalam bentuk dukungan material, informasi, bimbingan, bantuan fisik dan umpan balik dalam beraktifitas. Secara umum ditemukan sebagian besar perempuan dalam kegiatan politik di Sumatera Barat belum menerima dukungan social secara optimal dalam bentuk dukungan material, informasi, bimbingan, bantuan fisik dan umpan balik dalam 
beraktifitas $(46 \%=21.45 \%$ jarang +9.15 jarang sekali $+15.4 \%$ tidak pernah).

Menurut informan di lapangan mengungkapkan dukungan social telah diterima perempuan untuk aktif dalam kegiatan politik dari suami serta anakanaknya. Namuan dukungan social dari kerabat serta anggota organisasi di lingkungan Partati Politik kurang diterima oleh perempuan secara utuh. Tidak jarang perempuan apabila dipercayakan untuk menjalankan salah satu tugas penting di lingkungan masyarakat ditakut-takuti. Misalnya kalau perempuan ditunjuk menjabat sebagai Ketua RT. Diwaktu pemilihan laki-laki akan berpendapat nanti kalau ada kejadian bagaimana perempuan itu harus turun malam. Walaupun di Kelurahan/Nagari perempuan dan laki-laki dapat melakukan kemitraan secara bersamaan. Kerjasama dan berjaringan antara perempuan melalui organisasi perempuan (HWK, GOW) ditemukan masih terbatas. Kondisi ini menyebabkan pesan pemberdayaan terhadap perempuan kurang terwujud.

Meskipun perempuan mendapat dukungan sosial dalam kegiatan politik maupun dalam kegiatan sosial, maka tugas perempuan sebagai ibu dari anak anaknya , tidak bisa mengalihkan tugasnya kepada orang lain, terutama dalam hal kualitas perhatian dan pembinaan terhadap anak anaknya. Perempuan merupakan penanggung jawab yang ikut menentukan terciptanya keluarga sakinah.

\section{c. Partisipasi Politik Perempuan}

Berdasarkan hasil penelitian dan pengolahan data diperoleh informasi tentang partisipasi politik perempuan di Sumatera Barat dalam kegiatan politik seperti tabel berikut ini : 
Tabel 3

Distribusi Frekuensi Partisipasi Perempuan dalam Politik di Propinsi Sumatera Barat

\begin{tabular}{|c|c|c|c|c|c|c|c|c|c|c|c|c|}
\hline \multirow{3}{*}{ No. } & \multirow{3}{*}{ Indikator } & \multicolumn{10}{|c|}{ Kemungkinan Jawaban } & \multirow{3}{*}{$\mathrm{Jml}$} \\
\hline & & \multicolumn{2}{|c|}{ SS } & \multicolumn{2}{|c|}{$\mathrm{S}$} & \multicolumn{2}{|c|}{$\mathrm{J}$} & \multicolumn{2}{|c|}{ JS } & \multicolumn{2}{|c|}{ TP } & \\
\hline & & $\mathrm{f}$ & $\%$ & $\mathrm{f}$ & $\%$ & $\mathrm{f}$ & $\%$ & $\mathrm{f}$ & $\%$ & $\mathrm{f}$ & $\%$ & \\
\hline 1 & $\begin{array}{l}\text { Menyuarakan } \\
\text { Kepentingan }\end{array}$ & 97 & $\begin{array}{c}15.1 \\
6\end{array}$ & 312 & 48.75 & 123 & 19.22 & 36 & 5.63 & 72 & 11.25 & 640 \\
\hline 2 & $\begin{array}{l}\text { Memberikan } \\
\text { Kontribusi }\end{array}$ & 122 & $\begin{array}{c}10.8 \\
9\end{array}$ & 549 & 49 & 199 & 17.77 & 66 & 5.89 & 184 & 16.43 & 1120 \\
\hline 3 & $\begin{array}{l}\text { Mengontrol, } \\
\text { Perencanaan, } \\
\text { Pelaksanaan } \\
\text { dan Penilaian } \\
\text { Pembangunan }\end{array}$ & 98 & $\begin{array}{c}15.3 \\
1\end{array}$ & 247 & 38.59 & 138 & 21.56 & 33 & 5.16 & 103 & 16 & 640 \\
\hline & Jumlah & 317 & $\begin{array}{c}13.2 \\
1 \\
\end{array}$ & $\begin{array}{c}112 \\
9\end{array}$ & 47 & 460 & 19.18 & 135 & 5.63 & 359 & 14.97 & 2400 \\
\hline
\end{tabular}

Berdasarkan tabel di atas ditemukan sebanyak $48.75 \%$ perempuan di Sumatera Barat sering menyuarakan kepentingan perempuan dalam pengambilan kebijakan pemerintah. Selanjutnya $19.22 \%$ perempuan di Sumatera Barat mengungkapkan jarang, $15.16 \%$ sering sekali, $11.25 \%$ tidak pernah dan $5.63 \%$ jarang sekali menyuarakan kepentingan perempuan dalam pengambilan kebijakan pemerintah. Secara umum ditemukan sebagian besar perempuan di Sumatera Barat belum menyuarakan secara optimal kepentingan perempuan dalam pengambilan kebijakan pemerintah $(36.1 \%=19.22 \%$ jarang $+11.25 \%$ tidak pernah $+5.63 \%$ jarang sekali).

Selanjutnya ditemukan sebanyak $49 \%$ perempuan di Sumatera Barat mengungkapkan sering memberikan kontribusi dalam kegiatan politik. Kemudian $17.77 \%$ jarang, $16.43 \%$ tidak pernah, $10.89 \%$ sering sekali dan $5.89 \%$ jarang sekali perempuan di Sumatera Barat memberikan kontribusi dalam kegiatan politik. Dengan demikian sebagian besar perempuan di Sumatera Barat belum memberikan kontribusi secara optimal dalam kegiatan politik $(40.09 \%=17.77 \%$ jarang $+5.89 \%$ jarang sekali $+16.43 \%$ tidak pernah). 
Partisipasi perempuan dalam mengontrol dan menilai pembangunan ditemukan sebanyak $38.59 \%$ sering melakukan pengontrolan terhadap perencanaan, pelaksanaan dan penilaian pembangunan. Selanjutnya sebanyak $21.56 \%$ jarang, $16 \%$ tidak pernah, $15.31 \%$ sering sekali, dan $5.16 \%$ jarang sekali melakukan pengontrolan terhadap perencanaan, pelaksanaan dan penilaian pembangunan. Dengan demikian secara umum ditemukan sebagian besar perempuan di Sumatera Barat belum berpartisipasi secara optimal, dengan cara mengontrol perencanaan, pelaksanaan dan penilaian pembangunan (42.72 $\%=21.56 \%$ jarang $+16 \%$ tidak pernah $+5.16 \%$ jarang jarang sekali)

Apabila dikalkulasikan lebih lanjut ditemukan sebanyak $47 \quad \%$ perempuan di Sumatera Barat mengungkapkan sering berpartisipasi dalam kegiatan politik. Selanjutnya sebanyak 19.18 \% perempuan di Sumatera Barat mengungkapkan jarang, $14.97 \%$ tidak pernah, dan $13.21 \%$ mengungkapkan sering sekali dan 5.63\% jarang sekali berpartisipasi dalam kegiatan politik. Dengan demikian sebagian besar perempuan di Sumatera Barat belum berpartisipasi secara optimal dalam kegiatan politik $(43.33 \%=19.18 \%$ jarang $+14.97 \%$ tidak pernah $+5.63 \%$ jarang sekali).

Sebagian besar informan di lapangan mengungkapkan, kurang berpartisipasinya perempuan dalam kegiatan politik disebabkan oleh factor internal perempuan itu sendiri yang sering bersifat pemalu, kurang percaya diri serta beban ganda yang harus diselesaikan secara serempak. Kehidupan berkeluarga sangat menyita waktu dan pikiran. Kenyataan yang ditemui bagi perempuan yang aktif dalam kegiatan politik mereka didukung oleh suami dan anak-anaknya. Namun demikian dukungan tersebut tidak akan diperoleh dari anggota kerabat lainnya dan masyarakat. Didalam partai sering terjadi persaingan yang tidak sehat dan kaum laki-laki mendiskriditkan perempuan. Keberhasilan perempuan untuk menjadi tokoh di masyarakat sangat ditentukan oleh karakter dan ilmu pengetahuannya. Keberhasilan perempuan dalam bidang politik sangat ditentukan oleh sumber daya yang dimiliki perempuan itu sendiri di Kelurahan/Nagari.

Perempuan yang terpilih untuk menduduki posisi/jabatan tertentu belum tentu akan dapat menyuarakan kepentingan perempuan,. Pernyataan tersebut beralasan bahwa budaya diam ( silent cuilture) yang telah dikonstruksi oleh kultur masih mempengaruhi sikap perempuan untuk menyuarakan kepentingan 
perempuan. Oleh karena itu untuk memposisikan perempuan pada jabatan tertentu harus dipertimbangkan kapasitas dan kapabilitasnya. Pada prinsipnya menurut sebagain besar informan siapapun yang menjadi pemimpin sepanjang memiliki sensitivitas (kepekaan) gender, baik laki laki maupun perempuan, perlu diberikan dukungan. Dalam rangka mengejar ketertinggalan kaum perempuan dalam berbagai hal, maka pemimpin yang memiliki sensitivitas gender, sudah barang tentu akan menyuarakan kepentingan perempuan. Berbeda dengan pendapat sebagian ibu-ibu yang mengungkapkan pilihan terhadap calon perempuan diantara calon yang akan menempati posisi tertentu merupakan suatu yang wajar, mengingat perempuan yang banyak tahu tentang persoalan dan kebutuhan kaum perempuan yang mesti diakomodir dalam kegiatan pembangunan.

Dalam pemerintahan nagari maupun dalam kegiatan kemasyarakatan, dapat dilihat bentuk partisipasi perempuan lainnya dalam pembangunan pemerintahan nagari seperti kegiatan gotong royong masal yang dilaksanakan nagari. Sikap kebersamaan yang dipresentasikan dalam kegiatan gotong royong, ditunjukan dari kesediaan perempuan mengantarkan jedah ringan dan air minum atau mempersiapkan konsumsi makan siang. Sebagian besar responden mengungkapkan ibu-ibu merasa malu jika tidak dilibatkan peran sertanya dalam pembangunan nagari. Partisipasi dalam pemerintahan nagari tidak didasarkan atas pembedaan jebis kelamin, tetapi (laki laki dan perempuan secara bersama sama dituntut untuk berpartisipasi aktif dalam pembangunan nagari.

Memang terbatasnya partisipasi perempuan dalam politik tanpak pada tidak terpenuhinya qouta perempuan pada pemilihan umum lalu. Tidak terpenuhinya quota tersebut, menurut Informan di lapangan disebabkan oleh beberapa hal, yaitu : (1). kesempatan yang diberikan partai politik berdasarkan komposisinya sangat minim sekali. (2) terbatasnya pengetahuan perempuan dalam bidang politik, (3) beban kerja perempuan yang banyak sekali menjadi penyebab kurangnya kesempatan bagi kaum perempuan untuk berkiprah dan aktif dalam politik. Disamping terbatasnya pengetahuan dan kemampuan perempuan dalam politik kegiatan politik tidak cocok dengan fitrah kaum perempuan disamping keterbatasan kemampuan ekonomi perempuan juga menjadi penyebab rendahnya partisipasi perempuan dalam politik. 


\section{Pembahasan}

Berdasarkan hasil penelitian ditemukan sebagian besar perempuan Propinsi Sumatera Barat belum berpartisipasi secara optimal dalam kegiatan politik. Kondisi ini menunjukkan perempuan Sumatera Barat belum memiliki keterlibatan mental dan perasaan serta memberikan kontribusi dalam mempengaruhi penguasa/pemerintah dalam usaha mencapai tujuan pembangunan mulai dari perencanaan, implementasi, penilaian serta memanfaatkan dan menikmati hasil pembangunan secara optimal.

Apabila dikaji dari potensi perempuan yang aktif dalam kegiatan politik di Sumatera Barat sangat potensian. Di lihat dari segi umur sebagian besar perempuan yang aktif dalam kegiatan politik di Sumatera Barat berumur dari $30-$ 54 tahun (91.88 \%), dengan pendidikan sebagian besar berlatar belakang pendidikan tamatan SLTA sampai dengan sarjana ( $95.01 \%$ ) yang bekerja sebagian besar sebagai Ibu Rumah Tangga dan wiraswasta. Kondisi ini menunjukkan pengalaman dan pemahaman di bidang politik sangat terbatas.

Berdasarkan penelitian ditemukan sebagian besar perempuan Propinsi Sumatera Barat belum dapat menterjemahkan, menafsirkan dan extrapolari (mempertimbangkan/meramalkan) perlunya keterlibatan perempuan mempengaruhi kebijakan pemerintah dalam pengambilan keputusan. Hal ini menunjukkan pemahaman politik perempuan Sumatera Barat masih terbatas. Berdasarkan data kuliatatif ditemukan keterbatasan pemahaman politik perempuan disebabkan oleh kurangnya pengetahuan perempuan terhadap politik. Sebagian perempuan yang memiliki potensi takut aktif dalam kegiatan politik karena memaknai politik itu kotor dan jahat. Peningkatan pengetahuan perempuan terhadap politik dapat dilakukan melalui pendidikan politik terhadap perempuan dan masyarakat.

Selanjutnya lemahnya partisipasi politik perempuan, berdasarkan hasil penelitian ditemukan sebagian besar perempuan dalam kegiatan politik di Sumatera Barat belum menerima dukungan social secara optimal dalam bentuk dukungan material, informasi, bimbingan, bantuan fisik dan umpan balik beraktifitas dari keluarga, kerabat, masyarakat dan organisasi social lainnya. Berdasarkan data kualtiatif ditemukan dukungan sosial sudah diterima perempuan dari keluarga dan anak untuk aktif dalam kegiatan politik, tetapi tidak jarang 
faktor interen dan dukungan dari kerabat serta masyarakat dan teman-teman dilingkungan organisasi sosial masih terbatas. Tidak jarang persaingan tidak sehat sering terjadi sesama perempuan.

\section{Kesimpulan dan Rekomendasi}

\section{Kesimpulan}

Berdasarkan hasil penelitian dan pembahasan dapat disimpulkan sebagai berikut :

a. Sebagian perempuan Propinsi Sumatera Barat belum dapat menterjemahkan, menafsirkan dan extrapolari (mempertimbangkan/meramalkan) perlunya keterlibatan perempuan mempengaruhi kebijakan pemerintah dalam pengambilan keputusan.

b. Sebagian perempuan dalam kegiatan politik di Sumatera Barat belum menerima dukungan social secara optimal dalam bentuk dukungan material, informasi, bimbingan, bantuan fisik dan umpan balik beraktifitas dari keluarga, kerabat, masyarakat dan organisasi social lainnya.

c. Sebagian perempuan Propinsi Sumatera Barat belum berpartisipasi secara optimal dalam kegiatan politik .

\section{Rekomendasi}

Berdasarkan hasil penelitian mengenai partisipasi perempuan dalam bidang politik di Sumatera Barat, dikemukakan rekomendasi sebagai berikut

a. Pemahaman politik perempuan ditemukan belum optimal menterjemahkan, menafsirkan dan extrapolari (mempertimbangkan/meramalkan) perlunya keterlibatan perempuan mempengaruhi kebijakan pemerintah dalam pengambilan keputusan di Sumatera Barat. Untuk itu Biro Pemberdayaan Perempuan dirasa perlu meningkatkan program pengarus tamaan jender melalui lembaga pendidikan formal, Organisasi Sosial Kemasyarakatan, lembaga pemerintahan sampai ke Kelurahan/Nagari.

b. Dukungan sosial yang diterima perempuan dalam kegiatan politik, berbentuk dukungan material, informasi, bimbingan, bantuan fisik dan umpan balik dari keluarga, kerabat, masyarakat dan organisasi social lainnya di Sumatera Barat belum maksimal. Untuk itu diperlukan koordinasi antara Dinas Sosial, 
BKKBN, Koperasi, Biro Pemberdayaan Perempuan, Badan Pemberdayaan Masyakat, MUI, LKAAM dan Bundokanduang serta organisasi perempuan lainnya dalam penyusunan dan pelaksanaan program pengarustamaan jender dalam peningkatan pemahaman kesetaraan dalam bidang politik sesuai dengan kondisi dan kebutuhan masyarakat.

c. Dukungan sosial dari keluarga dan anggota kerabat lainnya serta masyarakat terhadap perempuan dalam kegiatan politik ditemukan kurang optimal. Untuk itu diperlukan Biro Pemberdayaan Perempuan meningkatkan program pengarustamaan jender dalam pemahaman politik bersama Dinas Sosial, BKKBN, BPM di kelurahan/nagari, mesjid, pesantren dan sekolah.

d. Dukungan dari lingkungan terhadap pemberdayaan potensi perempuan dalam kegiatan politik terasa lemah. Biro Pemberdayaan Perempuan, BPM dan Depag dirasa perlu merumuskan dan melaksanakan program pemahaman politik perempuan, keluarga dan masyarakat melalui konseling pernikahan, ceramah agama serta penyuluhan lainnya.

e. Biro Pemberdayaan Perempuan berkoordinasi dengan Depag, MUI, dan BPM dirasa pelu mengkoordinir Mesjid-mesjid dan Ulama, dalam merumuskan serta menetapkan kurikulum pengajian yang dapat meningkatkan pemahaman terhadap kesetaraan jender dalam bidang politik bagi perempuan, keluarga dan masyarakat.

f. Biro Pemberdayaan perempuan dirasa perlu mengoptimalkan program pengarustamaan jender bersama Dinas Pendidikan dengan jalan : peningkatan pemahaman guru melaksanakan proses pembelajar dalam peningkatan kesadaran berpolitik perempuan di setiap tingkat lembaga pendidikan, mengevaluasi kurikulum, bahan ajar serta pendekatan yang telah digunakan yang mensubordinatkan perempuan bergerak di bidang politik. 


\section{Daftar Kepustakaan}

Bloom, Benjamin and Masia (1999): Taxonomy of Education Objective Cognitive Domain. New York : Logman.

Burda,P.C. A. Vaux dan T. Schil, (1984). Social Support Resources : Variation Across Sex and Role, in Personality and Social Psychology Bulletin.10 119-126.

Burke,R.J. dan T. Weir (1978). Sex Differences In Adolescent Life Stress, Social support, and Well Being, in The Journal of Psychology. 98 (5) 277278.

Burleson, Brant R., Terrance L. Albrecht dan Irwin G. Sarason, (1994).

Comunication of Social Support : Messages, Interaction, Relationship, anda Communinity New Delhi : Sage Publications.

Bryant, Coralie \& Louise, White. (1992). Pengantar Metoda penelitian Kualitatif. (Alih Bahasa) Surabaya.

David, Korten C. (1980). Community Organitation and Rural Development a Learning process Approach.

Cole, L (1963). Psychology of Adolescence New York : Holt, Rinehart \& Winston, Inc.

Calhoun \& Acocella, ( 1995 ). Psikologi tentang Penyesuaian dan Hubungan Kemanusiaan. Semarang : IKIP SEmarang Press.

Darley, John M. Sam Glucksberg dan Ronald A. Kinchla. ( 1991 ) Psychology. New Jersey : Prentice Hall, Inc.

Drajat, Zakiah. (1993). Remaja Harapan dan Tantangan. Bandung : Remaja Rosdakarya Offset.

Dunkel - Schetter, C (1987). Correlates of Social Support Receipt. Journal of Medical Psychology. 61.17-36.

Faisal, Sanapiah. (1990). Penelitian Kualitati,: Dasar-dasar dan Aplikasi. Malang; YA3 Malang.

Fatmariza (2004) : Partisipasi Perempuan di Bidang Politik. Padang : Biro Pemberdayaan Perempuan Propinsi Sumatera Barat.

Ganster, D.C. dan B. Victor (1988). The Impact of Social Support on Mental and Psysical Health. British Journal of Medical Psychology. 61. 17-36.

Gerungan, WA. (1972), Psichology Sosial. Jakarta : PT Eresco.

Habibie, BJ, (1995) Ilmu Pengetahuan, Teknologi dan Pembangunan Bangsa; Menuju Dimensi Baru Pembangunan Indonesia. Jakarta ; CIDES. 
Hartiningsih, Maria (2003) : Membaca Filsafat yang "Bertubuh" dan "Berjender. Jakarta : www.jurnalperempuan.com/yjp.jpo/mar-rb.htm

Kementrian Pemberdayaan Perempuan RI (2003): Perempuan dan Politik. Jakarta : Kementrian Pemberdayaan Perempuan RI Jakarta.

Mubyarto. (1980). Meningkatkan Partisipasi Masyarakat dalam Pembangunan Minangkabau. LPPM Malang; Unibraw.

Nasution, Nursanita (2003) : Politik adalah bagian dari kehidupan Kita. Jakarta: www.rahima.or.id/SR/10-03/Opini1.htm

Peraturan Daerah Propinsi Sumatera Barat no. 9 tahun 2001 tentang Ketentuan Pokok Pemerintahan Nagari (lembaran Daerah Kabupaten Tanah Datar Tahun 2002 seri D). Tanah Datar.

Rahima, (2003): Politik Adalah Bagian Dari Kehidupan Kita. Jakarta : www.rahima.or.id/SR/10-03/Opini1.htm

Rasyid, Ryass (2000). Otonomi Daerah dalam Negara Kesatua, Yogyakarta: Pustaka Pelajar.

Sriemiyanti (2001) : Akses dan control Perempuan terhadap Hak-hak politik pada Pemilu 1999 di Medang, dalam Jurnal Pemberdayaan Perempuan Vol.1 No.1,8-15.

Sajogyo. (1996). Pembangunan Dearah dan Pemberdayaan Masyarakat. Jakarta

Sarason, N. R. I.G Sarason dan G.R Pierce (1990). Social Support : An Interactional View. New york : A Wilwy Interscience Publication.

Thoits, P.A. (1986). Social Support As Coping Assitance. Journal of Consulting and Clinical Psychology. 56 (4) 416-423

Sastropoetro. (1988). Partisipasi, Komunikasi, Persuasi dan Disiplin dalam Pembangunan Nasional. Bandung: Pustaka Alumni.

Slamet (1985). Pokok-pokok Pembangunan Masyarakat. Jakarta,: Bharata.

Undang-undang No 22 Tahun 1999 tentang Pemerintahan Daerah. Jakarta: sinar Grafika.

Undang-undang No 25 Tahun 1999 tentang Perimbangan keuangan Pemerintah Pusat dan Daerah. Jakarta: sinar Grafika.

Winkel, WS (1989) : Psikologi Pengajaran. Jakarta : Gramedia. 
